\title{
The Nitty-gritty of Language Learners' Errors - Contrastive Analysis, Error Analysis and Interlanguage
}

Bandar Mohammad Saeed Al-Sobhi*

English Language Department, General Directorate of Education, Jeddah, Saudi Arabia

Corresponding author: Bandar Mohammad Saeed Al-Sobhi, E-mail: bandarphd@gmail.com

\section{ARTICLE INFO}

Article history

Received: May 14, 2019

Accepted: July 21, 2019

Published: July 31, 2019

Volume: 7 Issue: 3

Conflicts of interest: None

Funding: None

\begin{abstract}
The major aim of the current paper is to review and discuss three prevailing approaches to the study of Second Language Acquisition (SLA) since the middle of the twentieth century: Contrastive Analysis (CA, henceforth), Error Analysis (EA) and Interlanguage (IL). It begins with a general overview of how the CA approach was formulated and developed and discusses the three versions of CA which were displaced later by other approaches, such as EA and IL. The paper also provides an in-depth theoretical discussion of the notion of EA in terms of its definitions, goals, significance, development, causes and procedures. The discussion about the SLA approaches concludes with a review of IL which claims that language learners produce a separate linguistic system with its own salient features, which differs from their L1 and target language. Additionally, a bulk of previous studies conducted on EA in different contexts are reviewed throughout the paper.
\end{abstract}

Key words: Contrastive Analysis, Error Analysis, Interlanguage

\section{CONTRASTIVE ANALYSIS: A HISTORICAL PERSPECTIVE}

Until today, scholars in the field of applied linguistics have continued to find ways to overcome the difficulties associated with language learning and teaching. A number of teaching approaches which were developed and employed in the middle of the twentieth century were based on linguistics and psychological theories of language learning. One of these is the audio-lingual approach which is derived from structural linguistics and behavourist language theory. Structural linguistics stresses on linguistic units such as sounds, words and sentences whereas behavourist language theory focuses on imitation, practice, encouragement and habit formation (Richards \& Schmidt, 2010). In fact, the previous research conducted in the 1950s by the structuralists and behaviourists such as Charles Fries, Edward Sapir, Charles Hockett and Burrhus Skinner (as cited in Brown, 2000, pp.910) led to the emergence of the CA approach, which focuses on comparing and contrasting two language systems. The basic purpose of this kind of comparison was exclusively pedagogical, i.e. used to prepare teaching and learning materials, tests and so forth (Awasthi, 1995). Fisiak (1981, p.1) defines contrastive linguistics as 'a sub-discipline of linguistics concerned with the comparison of two or more languages or subsystems of languages in order to determine both the differences and similarities between them'. Accordingly, a linguist may compare and contrast two phonetic systems or syntactic systems such as Arabic and English to determine the difficulties which language learners encounter and identify the challenges which teachers face while teaching the target language.

Fisiak (1981) divided contrastive studies into two forms: theoretical and applied studies. On one hand, theoretical contrastive studies provide a comprehensive description of the similarities and differences between two or more languages, propose an adequate model for their comparison and identify the comparable elements of the two languages. On the other hand, applied contrastive studies, which is subsumed under applied linguistics, provides a framework for the comparison of languages based on the results of the theoretical contrastive studies, and select the necessary data for a particular purpose, such as teaching, translation, bilingual analysis etc. (Fisiak, 1981; Keshavarz, 2003). In addition, contrastive applied studies 'are concerned with probable areas of difficulty in another language where a given category is not represented in the surface structure and interference is likely to occur' (Fisiak, 1981, p. 3). For instance, Arab learners of English find it difficult to pronounce English consonant sounds such as $/ \mathrm{p} /$ and $/ \mathrm{v} /$ perhaps because the two sounds do not exist in Arabic. The $/ \mathrm{p} /$ and $/ \mathrm{v} /$ sounds are normally substituted with /b/ and /f/, respectively. Thus, words like push and van are pronounced incorrectly as bush and fan. Such mispronunciations occur due to what is known as the linguistic negative transfer - 'an inappropriate influence of an L1 structure or rule on L2 use' (Saville-Troike, 2006, p. 192) - which is one of the primary assumptions of CA. 


\section{Contrastive Analysis Hypothesis (CAH)}

According to Richards and Schmidt (2010), CA is based on three primary assumptions. First, the major difficulties in learning another language occur basically due to the learner's native language interference. Second, such difficulties can be predicted by carrying out a CA, i.e. through a comparison between the two linguistic systems, i.e. the leaner's native language and the target language. The third assumption is, in order to minimise the effects of linguistic interference, teaching materials are prepared. The assumptions describe language learning as a set of habit formation that occurs through imitation or reinforcement (Ellis, 1985). In other words, a learner copies and repeats a certain behaviour until it becomes spontaneous and he is either rewarded or punished depending on his responses.

Robert Lado, a strong proponent of CA, used the earlier studies conducted on bilingualism, besides his personal observations and experience as native speaker of Spanish, to validate these assumptions. He noticed that learners "tend to transfer the forms and meanings, and the distribution of forms and meanings of their native language and culture to the foreign language and culture" (Lado, 1977 cited in Keshavarz, 2003, p.5).

Selinker and Gass (2008) summarised a number of assumptions on which CA is based. To begin with, language learning is considered as a set of habits based on the concepts of stimulus and response. While learning takes place, the learner's successful responses are reinforced and then repeated to form a habit. Accordingly, learning a second language means the formation of a new set of linguistic habits. However, difficulties arise during the L2 learning process because the learner's well-formed first-language habits interfere with the learning of the target language. Consequently, the main cause of difficulty in learning another language originates from the learner's native language, and difficulties arise due to the differences between the two languages. Accordingly, the greater the differences, the more errors are expected to occur in the learner's interlanguage. Selinker and Gass also added that a language learner needs to merely learn the differences, and ignore the linguistic features that are similar because they are repetitive in both languages and therefore do not create any difficulties. This view reflects the strong version of the CA perspective, which considers interference as the main cause of difficulty in learning a second language.

In language learning, the terms transfer and interference are not synonymous. The notion of transfer is of two types: positive transfer and negative transfer. Dulay, Burt and Krashen (1982, p. 97) define positive transfer as 'the automatic use of the L1 structure in L2 performance when the structures in both languages are the same, resulting in correct utterances.' Accordingly, positive transfer takes place when the native language shares some similar linguistic elements with the target language. On the other hand, negative transfer, also known as interference, results from the differences between the two language systems. Such differences make learning the target language difficult and increase the possibility of committing errors in the interlanguage of the learner. Lado (1977) claims that the key to ease, or difficulty, in learning another language depends on the similarities and differences between the first language and the target language. Awasthi (1995, p. 35) emphasises that 'the more the differences between L1 and L2, the more difficulties the learners are likely to face resulting in the erroneous utterances.' Thus, a comparison between two language systems facilitates the learning process and helps teachers select the most effective teaching materials (Powell, 1998). However, this strong view is not shared by other proponents of the CA approach. This resulted in three different versions of the approach: strong, weak and moderate.

\section{The Three Versions of the CA}

As mentioned earlier, the learner's native language is of great significance in learning a second language. In learning another language, a learner finds some easy and difficult linguistic features to master, which can either accelerate or decelerate his language learning process. Thus, the features which are similar to his native language can be understood easily and thus easy to learn, but difficulties arise when a learner comes across different linguistic elements that are different from those of his native language. This perspective forms the strong version of the CA which emphasises that interference in learning the target language is a result of differences between the native language system and the target language system, which is the prime cause of second language learning difficulty.

As far as difficulty prediction is concerned, Lado (1977, p. vii) claims that 'we can predict and describe the patterns that will cause difficulty in learning, and those that will not $\ldots$ by comparing systematically the language and the culture to be learned with native language and culture of the student.' Brown (2000, p. 209) suggests six possible levels of difficulty (as illustrated in Table 1), arranged in ascending order for comparing and contrasting the grammatical and phonological system of two languages. The first level, 'Level 0', represents the positive transfer in which the linguistic items in the first language appear identical to those in the target language. Thus, language learners experience no difficulty while learning the target language because of zero interference. On the contrary, the fifth level 'split' represents the highest level of interference which requires a learner to exert an enormous effort while learning the second language due to the difficulty he encounters. Most of the examples illustrated in the table below concern the phonological system of two languages as it is a fundamental component in learning.

The hierarchy of difficultly outlined above and the procedures suggested by Ellis (1985) for CA are quite insufficient due to certain reasons. First, Wardhaugh (1975 as cited in Brown, 2000, p. 211) found that the strong version is neither realistic nor practicable. He stated that 'this version demands of linguists that they have available a set of linguistic universals formulated within a comprehensive linguistic theory which deals adequately with syntax, semantics, and phonology'. In addition, it is not quite easy to determine precisely the level of difficulty of a particular contrasting item. Brown 
Table 1. Levels of difficulty

\begin{tabular}{|c|c|}
\hline Levels & Description \\
\hline $\begin{array}{l}\text { Level } 0 \\
\text { Transfer }\end{array}$ & $\begin{array}{l}\text { No difference between L1 and L2, } \\
\text { and the learner can positively transfer } \\
\text { some linguistic items from L1 to L2, } \\
\text { e.g., sounds like/b/,/t/,/d/,/k/,/f/can be } \\
\text { found in Arabic and English. }\end{array}$ \\
\hline $\begin{array}{l}\text { Level } 1 \\
\text { Coalescence }\end{array}$ & $\begin{array}{l}\text { Two items in L1 merged into one item } \\
\text { in L2, e.g., French learners overlook } \\
\text { the difference between teach and learn, } \\
\text { and they use apprendre instead. }\end{array}$ \\
\hline $\begin{array}{l}\text { Level } 2 \\
\text { Under-differentiation }\end{array}$ & $\begin{array}{l}\text { An item in } \mathrm{L} 1 \text { does not exist in } \mathrm{L} 2 \text {, } \\
\text { e.g., the sounds/p/and/v/do not exist } \\
\text { in Arabic. Thus, English learners of } \\
\text { Arabic must avoid these sounds when } \\
\text { practicing Arabic. }\end{array}$ \\
\hline $\begin{array}{l}\text { Level } 3 \\
\text { Reinterpretation }\end{array}$ & $\begin{array}{l}\text { An existing item in L1 is given a new } \\
\text { shape or distribution in L2, e.g., dark } \\
\text { and light/l/are heard in Arabic, } \\
\text { however, Arabic speakers learning } \\
\text { English need to learn the phonological } \\
\text { environments of the two to avoid } \\
\text { mispronouncing words, such as total } \\
\text { and hospital. }\end{array}$ \\
\hline $\begin{array}{l}\text { Level } 4 \\
\text { Over-differentiation }\end{array}$ & $\begin{array}{l}\text { A completely new item must be learnt } \\
\text { in L } 2 \text { because of little or no similarity } \\
\text { to L1. Arabic speaker must learn the } \\
\text { English phonemes such as } / \mathrm{p} /, / \mathrm{v} / \text {, } \\
/ \mathrm{t} / /, / \mathrm{d} / \text {. }\end{array}$ \\
\hline $\begin{array}{l}\text { Level } 5 \\
\text { Split }\end{array}$ & $\begin{array}{l}\text { Unlike coalescence, split represents } \\
\text { an item in L1 becoming two or more } \\
\text { in L2. This requires a learner to make } \\
\text { a new distinction. Arabic learners of } \\
\text { English have to make a distinction } \\
\text { between/J/and /t } \mathrm{t} / \text { as in shoes and } \\
\text { choose. }\end{array}$ \\
\hline
\end{tabular}

(2000, p. 211) states that 'the most problematic issue of the strong version was whether the predictions of difficulty levels are verifiable or not'.

Ellis (1985) proposed the following four-stage procedure in which two language systems can be compared and contrasted. First, a linguist formally needs to describe the two languages, and then select certain linguistic items. These items are subsequently compared and contrasted with each other and followed by the identification of the areas that are likely to cause errors. In this light, the strong version of CA was successful in predicting the interference based on the differences between the phonological components of L1 and L2. Nonetheless, it is not quite adequate at predicting the interference in other language areas such as grammar. In their study, Dulay et al. (1982, pp. 97-98) concluded that the CA approach is a weak predictor of learner's performance. Their research revealed the following results about the CA approach:

1. In neither child nor adult L2 performance do the grammatical errors reflect the learner's L1.

2. L2 learners make many errors of grammar that are comparable in both the L1 and L2 errors that should not be made if 'positive transfer' were operating.
3. L2 learners' judgements of the grammatical correctness of L2 sentences are more related to L2 sentence type than to their own L1 structure.

Unlike the strong version which claims that second language learner's difficulties and errors can be predicted before they have been made, the weak version (known today as cross-linguistic influence) does not imply prior prediction of certain degrees of difficulty. In this version, errors are studied after they have been committed by second language learners, and the explanation of the causes is provided after analysing the learner's errors. In this light, it seems that the weak version is more realistic and practicable than the strong version. Brown (2000, p.211) points out that 'the weak version [does not only] recognise the significance of interference across languages, the fact that such interference does exist and can explain difficulties, but it also recognises that linguistic difficulties can be more profitably explained a posteriori', i.e. after they have been observed. A diagnosis of the errors committed by the learner helps teachers of second languages to understand their students' causes of errors.

On their spelling error research, Oller and Ziahosseiny (1970) proposed a compromise between the two versions of CA labeled as "the moderate version" which does not only focus on the contrast between the two languages but also on the nature of human learning. As far as English spelling is concerned, the moderate version predicts that students whose native language employs a non-Roman script (Arabic, Chinese) will make significantly fewer spelling errors than students whose native language uses a Roman alphabet, such as French and Malay. Brown (2007) illustrates this by saying that learning the rules of an entirely new game is perhaps easier than one that has quite similar rules or skills already learnt, that is, interference can actually be greater when the items to be learnt are more similar to the existing ones. The strong version which claims that learners who are exposed to an entirely new writing system are expected to experience more difficulty in terms of spelling rules. However, Oller and Ziahosseiny (ibid) found the opposite to be true. They concluded that most common spelling errors were due to intralingual (within one language) confusions. Similarly, Brown (2007) points out that the greatest difference between the learner's mother tongue and the target language does not necessarily cause great difficulty, and the causes of errors can either be intralingual (within one language) or interlingual (across two languages).

\section{Criticisms of the Contrastive Approach}

The inability to achieve the objectives of the CA approach which were formulated by the behaviourists in the fifties caused it to be bitterly criticised by many second language researchers and linguists, such as Chomsky (1959) who claimed that 'children do not learn their mother tongue as a set of habits, but rather as mental rules' (as cited in Ellis, 1994, p. 44). He also attacked the CA idea of comparing the results of animal learning experiments with human learning and behaviour. Accordingly, the claim that language learning is a set of habit formation developed by imitation, repetition and reinforcement was rejected. According to 
Selinker and Gass (2008), the assumption that language learning is an active rule formation behaviour instead of habit formation behaviour challenged CA and ultimately led to its demise. Empirical studies conducted by the likes of Nemser (1971); Corder (1981) and James (2013) showed that errors cannot be solely attributed to the learner's first language. In their studies of learner errors, Dulay and Burt (1974) revealed that, in spite of many errors committed by transferring first language habits, many more were not, and learners often contributed creatively to the process of learning. They reported that only less than five percent of the errors made by the learners were due to their first language, Spanish. Dulay et al. (1982, p.183) found that 'like L1 learners' errors, most of the errors L2 learners make indicate that they are gradually building an L2 rule system'. In other words, foreign/second language learners go through stages of acquisition, and the nature of their errors differ from one development level to another. Additionally, CA is criticised for ignoring factors which may affect the actual learner's production, i.e. use of language such as learning and communication strategies, overgeneralisation and so forth. (Keshavarz, 2003).

Despite these bitter criticisms towards CA, many language teachers around the world still find it quite useful when dealing with the language learner's difficulties which could be due to the linguistic differences between the L1 and the target language. In addition, Spolsky (1979, p.253) claims that 'CA encourages the linguists to describe the type of language that a language teacher needs for his teaching'. Nickel (1971, p.15) also points out that 'both teacher and the author require a knowledge of contrastive grammar in order to predict, explain, correct and eliminate errors due to interference between source and target language.' To conclude, it must be emphasised that the CA approach has greatly contributed to the field of language pedagogy and has played a significant role in the preparation of language syllabi, textbooks and teaching resources, which help a learner overcome the difficulties encountered while learning a foreign/second language. Scholars' dissatisfaction with the CA approach has shifted their attention to a more effective and practical method of analysis, i.e. Error Analysis.

\section{ERROR ANALYSIS}

Unlike the CA approach, which is connected to the behaviourist learning theory, EA is associated with the mentalist theory. During the 1970s, the use of CA began to decline as research showed that many L2 errors were not a result of interference, and L2 learners pass through stages of acquisition which make their errors vary from one development level to another. In order to overcome the weaknesses of the CA hypothesis, second language researchers began to look for an alternative method to study language learners' errors which would be theoretically justifiable and pedagogically effective and practicable (Keshavars, 2003). The results of the empirical studies conducted by applied linguists in the late 1960s and 1970s, for example, (Corder, 1973, 1978, 1981; Selinker, 1972; Richards, 1974 etc.) led to the emergence of EA, which marked a reform movement in the field of applied linguistics. Stephan Pit Corder, the pioneer of EA, made a clear theoretical distinction between performance analysis, which is 'the study of the whole performance data from individual learners', and EA, which is 'the study of the erroneous utterances produced by groups of learners' (1975, p. 207 as cited in James 2013, p.3). In line with a growth of research employing EA, many definitions of the methodology were also offered by second language researchers as illustrated in Table 2 below.

\section{The Differences between Errors and Mistakes}

There is no doubt that committing errors is a natural thing because it is part of human behaviour. While learning a skill, e.g. driving a car, swimming, or using a language, learners make countless errors in their initial attempts. However, these errors taper off and are reduced progressively as the learner gains more experience and applies the necessary knowledge. Brown (2000, p. 216) notes that 'the first mistakes of learning to swim are giant ones, gradually diminishing as you learn from making those mistakes.' In learning a language, errors have been defined differently by different researchers. Ferris, for instance, $(2011$, p. 3) defines errors as 'morphological, syntactic, and lexical forms that deviate from rules of the target language, violating the expectations of literate adult native speakers.' In the same vein, Corder (1981) describes an error as a systemic defect caused by a learner's lack of linguistic competence. Thus, a learner's errors result from his lack of linguistic knowledge and awareness rather than performance. But, is there a substantial difference between errors and mistakes?

Table 2. Definitions of error analysis

\begin{tabular}{ll}
\hline Linguist & Definition \\
\hline Corder & $\begin{array}{l}\text { An experimental technique for validating } \\
\text { the theory of transfer aims at telling us } \\
\text { something about the psycholinguistic } \\
\text { processes of language learning. }\end{array}$
\end{tabular}

Ellis, A procedure used by both researchers

(1985, p. 296) and teachers. It involves collecting samples of learner language, identifying the errors in the sample, describing these errors, classifying them according to their hypothesized causes, and evaluating their seriousness.

Selinker and Gass A procedure for analysing second language (2008, p. 517) data that begins with the errors learners make and then attempts to explain them.

Crystal, A technique for identifying, classifying and (2008, p. 173) interpreting systematically the unacceptable forms produced by someone in learning a second language, using the principles and procedures provided by linguistics.

VanPatten and A research tool characterized by a set of Benati (2010, p. 82) procedures for identifying, describing, and explaining L2 learners' errors.

James,

(2013, p. 1)
A process of determining the incidence, nature, causes and consequences of unsuccessful language. 
In EA, the notion of error takes on a specific meaning, i.e. a meaning that is different from that of 'mistake'. Corder (1981) clearly distinguishes between 'errors' and 'mistakes'. He states that errors are 'failures in competence' whereas mistakes are 'failures in performance'. He added that unlike mistakes, errors are systematic because they reveal the underlying linguistic knowledge of language learners. However, mistakes are non-systematic, i.e. learners do not commit mistakes because of deficiency in competence but rather a failure in performance due to their internal and external conditions when they write or speak. That is to say, learners' mistakes occur due to 'memory lapses, physical states such as tiredness and psychological conditions such as strong emotion' Corder (1981, p. 10). In other words, they occur when learners feel stressed, nervous, tired, anxious etc. Based on the distinction above, learners' slips of tongue or pen are considered 'mistakes' not errors if they are self-corrected, i.e. without external help, whereas they are considered 'errors' if not. Self-correction (James, 2013 suggests the term corrigibility) plays a crucial role in distinguishing errors from mistakes. Furthermore, learners' errors and mistakes are different in terms of intentionality. James (2013) points out that the learners' intention is important to determine whether the learner commits an error or a mistake. He explains that learners' errors are not committed deliberately whereas mistakes are.

On a different stance, Littlewood, (1984, p. 21) asserts that learner's errors are 'the clearest evidence for the learning developing systems and can offer us insights into how they process the data of the language.' In spite of what has been said about the differences between errors and mistakes, Ellis (1997) notes that it may not be always possible to draw a clear distinction between them.

\section{Stages of a Learner's Errors}

As mentioned earlier, the learners' errors are systematic. That is to say, the errors occur due to the learners' lack of competence rather than their failure of performance. Based on this systematicity, Brown (2007) describes four stages of learners' errors: presystematic, emergent, systematic and postsystematic. In the first stage, a leaner commits random errors due to his ignorance of the rules of the target language. Accordingly, he makes rough guesses at what to write, e.g. She cans play the piano, She is can play the piano. In the emergent stage, the learner seems to have grasped certain rules, but he is still unable correct his errors. In the third stage, the learner begins to detect and discover the rule and he is able to correct his errors when they are pointed out. Finally, the learner can self-correct himself without receiving feedback from others.

\section{Significance of Learners' Errors}

In language learning, errors are considered an undesirable aspect of language learning process because they have a negative effect and hinder learning from progressing (López, 2009). However, there are some convincing reasons for studying learners' errors. First, errors are noticeable features of learners' spoken or written language, which motivated applied linguists to raise the significant question 'Why do learners make error?'(Ellis, 1997). In order to answer this question, language researchers investigate the development of learners' language to identify the main causes of errors and then suggest an effective error treatment. Applied linguists (for example, Corder, 1973, 1981; Richards, 1974; Ellis, 1997; James, 2013; Brown, 2007; Selinker \& Gass, 2008) emphasised the high value and importance of language learners' errors. To them, errors are considered as signs that indicate the strategies the learners are using to acquire a language. Corder (1981) asserts that learners' errors are positive and important as they provide us with evidence of learning development, i.e. they are viewed as a linguistic device which demonstrates how a learner's language is developed. In a very real sense, errors are considered windows into the language learners' mind (Saville-Troike, 2006). Corder (1981) was among the first applied linguists who pointed out that learners' errors are highly significant in three respects:

First, to tell the teacher how far towards the goal the learner has progressed and, consequently, what remains for him to learn. Second, they provide to the researcher evidence of how language is learned or acquired, what strategies or procedures the learner is employing in his discovery of the language. Thirdly, to the learner because we can regard the making of errors as a device the learner uses in order to learn (p. 12).

Corder (1981) also argues that mistakes are of no importance to the process of language learning since they do not reflect a defect in our language, whereas errors, on the other hand, are of importance; they do reflect knowledge; they are not self-correctable; and only learners of an L2 make them'. In addition, Dulay et al. (1982) state that learners' errors are studied for two main purposes. One is to provide researchers with information about the nature of language learning process and how interference takes place. The other is to help teachers and curriculum designers determine the likely errors and difficulties which make the learner unable to communicate effectively. Richards and Schmidt (2010) mention that EA is carried out to identify the causes of a learner's errors as well as the difficulties he encounters while learning. He adds that EA also tells us about the strategies the student uses while learning a language. Sercombe, (2000) also stresses that analysing learners' errors is of high importance because it greatly helps researchers explore how students learn a language, and what level of proficiency they have reached. In addition, recent research conducted by El-Dakhs and Mitchell, (2011); Zawahreh, (2012); and Swalameh, (2013) on learners' EA view errors positively and strongly agree that learners' errors are extremely significant and fruitful as they help language researchers and teachers understand the process of second language acquisition and how it develops.

From a pedagogical perspective, a language teacher who is aware of his students' repeated errors can successfully prevent their future occurrence. In this way, the teacher's awareness of errors plays an important role as it can facilitate his task while giving the lesson. Sridhar (1980) claims that learners' errors make language teachers prepare their lessons carefully, set better exercises and tests, and select the appropriate teaching resources. Weireesh (1991) points out 
that EA serves as a reliable feedback to design a remedial teaching method and material. He adds that it is a valuable aid through which language learners' difficulties can be identified and explained.

\section{Procedures of Error Analysis}

Corder (1974) describes a four-stage procedure of EA approach which was widely used by researchers in the field of applied linguistics. These procedures are adequately explained in the following subsections:

\section{Collection of a sample of learner language}

Collecting sufficient data is the first important stage for any successful EA study. Thus, the researcher's choice and decision about the samples of learner's spoken or written language for the analysis plays a crucial role in exploring the learners' language and provides an understanding of how language works. In this light, collecting insufficient or inaccurate data can lead to a major effect on the results of the research. In order to obtain information from the samples, Corder (1981) identifies two elicitation techniques: clinical and experimental. The former involves getting the participant to produce data of any type, for example, by conducting an interview, asking the learner to write a free composition or translate a written text into the target language. On the other hand, the experimental technique involves the use of an instrument that is specially designed to elicit the required data from the participants.

As far as sample size is concerned, three types of samples: massive, specific and incidental, were identified by Ellis (1994). A massive sample involves collecting different samples of language from a large population of learners in order to compile a complete list of errors. An example of this is the Birkbeck Spelling Error Corpus which includes 36,133 misspellings of 6,136 target words (Zampieri \& Amorim, 2014). A specific sample, on the other hand, comprises a small number of leaners while an incidental sample involves merely one sample of language use produced by an individual learner. Most previous studies of EA have shown that collecting the data from a massive sample is a time-consuming process, and research findings obtained by an incidental sample cannot be generalised to a wider population (Ellis, 1994). However, language researchers prefer specific sample type to the other types because it is more manageable, practical and less time-consuming.

\section{Identification of leaners' errors}

At this stage, it is important to decide what constitutes an error and to follow a certain procedure to detect it. It is imperative at this stage to be able to clearly distinguish between the learners' errors and mistakes in the data. Ellis (1997) proposes two useful techniques to differentiate between errors and mistakes. The first technique enables the language researcher to check the consistency of the learner's performance. In a spelling test, if the word farmasy is repeatedly used for pharmacy, this would be classified as an error because it indicates the learner's lack of knowledge about the word. However, if the word 'pharmacy' is spelt correctly in many sentences but wrongly spelt in one instance, it is then considered a mistake because it suggests that the learner is aware of the correct spelling but made a slip in performance. To ascertain this, the learner can be asked to self-correct the misspelt words that have been underlined. Consequently, the learner's errors are those which he cannot self-correct whereas mistakes are those he can.

At the sentence level, Corder (1981) makes a distinction between 'overtly erroneous' sentences and 'covertly erroneous' ones. Learners' overt errors are easy to identify because they are ungrammatically formed, i.e. not conforming to the rules of the target language as in *I am not interested from sports or *He comed to school early instead of ' I am not interested in sports' and 'He came to school early'. On the other hand, covertly erroneous sentences are superficially well-formed, but it is not acceptable unless it is shown in a wider context. For instance, the sentence *I'm a student is grammatically correct, but it is wrong and meaningless if said in response to the question What are you doing here? rather than What do you do?. Other examples can be shown in the inappropriate word choice such as substituting house, beautiful with home and handsome in sentences like *Let's go house and *He's a beautiful man rather than Let's go home and He's a handsome man. Corder (1981) identifies three kinds of interpretations of errors: normal, authoritative and plausible. Normal interpretation takes place when the analyst understands the meaning of the sentence based on the rules of the target language while authoritative interpretation requires the analyst to ask the learner about the meaning of his sentence. On the other hand, plausible interpretation can be extracted by examining the context of the sentence or translating the sentence into the learner's L1. When learners' errors are fully identified, they must then be classified under categories of description.

\section{Description of a learner's errors}

The researcher, at this stage, organizes errors collected based on certain categories. Unfortunately, the task carried out to describe learners' errors is considered difficult because the learner's language system is unstable and cannot be directly observed (Brown, 2000). Thus, language researchers such as Burt and Kiparsky, (1972); Politzer and Ramirez, (1973); Corder, (1981); Dulay et al. (1998) and Cook, (1999) have not proposed a similar classification of learners' errors but rather described them based on the analysis of their studies.

The first classification of learners' errors was made by Burt and Kiparsky (1972) who detected thousands of errors made by non-native speakers of English. Their classification of errors was based on six linguistic categories, namely, (a) The Skeleton of English clauses (b) The auxiliary system, (c) Passive sentences, (d) Temporal conjunctions, (e) Sentential complements, and (e) Psychological predicates. An example of the first category is shown in Table 3 below:

In 1973, Politzer and Ramirez studied the spoken responses of 120 Mexican-American pupils studying in the United States. They identified the pupils' errors and classified them 
according to three main categories: morphology, syntax and vocabulary (see Table 4). The studies conducted by Burt and Kiparsky (1972) and Politzer and Ramirez's (1973) were merely descriptive as they did not provide any explanation for the causes of errors identified. Dulay et al., (1982, p.146) point out that descriptive classification serves two purposes: 'to present error categories which rely solely on observable characteristics for their definition and to report the findings of research conducted to date with respect to error types observed'

On the other hand, Corder's classification of error (1981) was based on combining certain linguistic categories with surface structures; namely omission, addition, selection and misordering. He claims that such classification is more abstract and systematic. Thus, he proposes four linguistics categories for errors: orthographic, phonological, grammatical and lexico-semantic. First, most orthographic errors occur due to the lack of one-to-one correspondence between the English phonemes and graphemes, and vice versa. Thus, English spelling is frequently described as a challenging task for foreign/second language learners. For example, the phoneme/k/can be represented differently as in car, school, kind, account, back and queen. On the contrary, the grapheme $<\mathrm{i}>$ can have different pronunciations as in bit, bite, machine and firm. Second, phonological errors arise from the absence of some phonemes in the learners' mother tongue. For instance, phonemes such as/p/and/v/do not exist in Arabic.

Table 3. A sample linguistic category taxonomy (Dulay et al., 1982)

\begin{tabular}{ll}
\hline Linguistic Category & Example of Learner Error \\
\hline $\begin{array}{l}\text { 1. Missing parts } \\
\text { a. Surrogate subject missing: } \\
\text { there }\end{array}$ & Was a match last night? \\
$\begin{array}{l}\text { b. Simple predicate missing: } \\
\text { be }\end{array}$ & You not old enough to drive \\
$\begin{array}{l}\text { c. Object pronoun missing: it } \\
\text { d. Subject pronoun missing: }\end{array}$ & I bought in Japan. \\
$\begin{array}{l}\text { they } \\
\text { 2. Misordered parts }\end{array}$ & \\
$\begin{array}{l}\text { a. verb before subject } \\
\text { b. subject and object }\end{array}$ & Escaped the man from prison. \\
substituted & English use many countries. \\
\hline
\end{tabular}

Table 4. Classification of learners' errors (Politzer and Ramirez, 1973)

\begin{tabular}{lll}
\hline Category & $\begin{array}{l}\text { Types of } \\
\text { Learners' errors }\end{array}$ & $\begin{array}{l}\text { Examples of } \\
\text { Learners' errors }\end{array}$ \\
\hline Morphology & $\begin{array}{l}\text { Omission of } \\
\text { possessive's }\end{array}$ & the man head \\
Syntax & $\begin{array}{l}\text { Use of pronouns } \\
\text { Omission of } \\
\text { subject pronouns } \\
\text { Omission of object } \\
\text { pronouns }\end{array}$ & $\begin{array}{l}\text { I don't know (it) in } \text { in } \\
\text { English }\end{array}$ \\
& $\begin{array}{l}\text { Incorrect word } \\
\text { choice }\end{array}$ & $\begin{array}{l}\text { The ant has an open } \\
\text { (Open used as a }\end{array}$ \\
& & $\begin{array}{l}\text { noun, for hole) } \\
\text { Vocabulary }\end{array}$
\end{tabular}

Therefore, Arab learners are expected to write or say This is a fery sharming blace to fisit rather than This is a very charming place to visit. Third, grammatical error occurs due to the learner's ignorance of the L2 system. However, Corder (1981) did not provide an in-depth description of the grammatical errors, but he suggested that learners' grammatical errors could be categorised in terms of systems such as tense, voice, mood and case as shown in Table 5 below.

Finally, lexico-semantic errors occur when a learner fails to select the right word for a certain context such as selecting clocks, learns and aloud for hours, teaches, and allowed as in 'This shop is open 24 clocks', 'Mr. Al-Ahmad learns us grammar' and 'Kids are not aloud to enter the museum'.

Additionally, Dulay et al. (1982) proposed four types of error taxonomy: the linguistic category, discussed previously (in Table 3), surface strategy, comparative analysis and communicative effect. The last two types deal with the causes of errors and will be discussed in the subsequent subheading. Surface strategy, which is the second strategy proposed by Dulay et al., (1982) makes a researcher realise that learners' error do not occur haphazardly or due to their laziness or sloppy thinking, but that they occur in a systematic way.

Cook also (1999) proposes four main types of classification of learners' errors: omission, insertion, substitution and transposition. Whilst omission is the 'absence of an item that must appear in a well-formed utterance' as in nife, clas for knife, class, insertion is the opposite because it takes place when an alphabet is inserted incorrectly as in carefull, firist, instead of careful, first. Furthermore, substitution occurs when the learner replaces the right form with an incorrect one, such as skool, bebol for school, people. Finally, transposition is caused by placing letters or words incorrectly as in becuase, freind instead of friend, because.

\section{Explanation of learners' errors}

As discussed earlier, the advocates of CA in the 1950s and 1960s believe that negative transfer is the principal cause of the L2 learners' difficulties and errors. In EA, a difficulty arises when a researcher attempts to identify the causes of learners' errors because many errors seem to have different origins. Dulay et al. (1982, p.197) point out that "the explanation of error types is not simply a matter of assigning a single source to each that occurs. It will have to be multidimensional and include factors beyond the observable

Table 5. A sample of learners' grammatical errors (Corder, 1981)

\begin{tabular}{|c|c|}
\hline $\begin{array}{l}\text { Grammar } \\
\text { categories }\end{array}$ & Examples \\
\hline Tense & $\begin{array}{l}\text { They have watched two movies yesterday. } \\
\text { I born in Kuala Lumpur }\end{array}$ \\
\hline Voice & $\begin{array}{l}\text { The letter is sent yesterday } \\
\text { The package has wrapped already }\end{array}$ \\
\hline Mood & $\begin{array}{l}\text { I suggest he starts now } \\
\text { I wish I speak Chinese }\end{array}$ \\
\hline Case & $\begin{array}{l}\text { This car is my } \\
\text { Don't talk to they }\end{array}$ \\
\hline
\end{tabular}


characteristics of the errors." Accordingly, learners' errors may arise from transferring L1 elements into L2, overgeneralising L2 rules, learner's ignorance of L2 rules, devising poor learning or teaching strategies, and so forth. Corder (1973), claims that linguistic interference is the clearest evidence to explain learners' errors. He adds that errors also result from the learners' false hypothesis which occurs due to their lack of comprehension of L2 rules. However, other applied linguists such as Richards (1974), Dulay et al. (1982), Taylor (1986), and James (2013) identified different causes of errors other than the negative transfer and learners' faulty hypothesis.

Richards (1974) observed the errors produced by learners from different non-English backgrounds (e.g. Japanese, French, Polish and Indians). His observation and analysis revealed that learners' errors are of two main types: interlingual and intralingual. Interlingual errors result from mother tongue interference whereas intralingual errors are those resulting from factors other than mother tongue interference. Brown (2007) points out that interlingual errors frequently occur at the beginning of learning a foreign/second language, i.e. the learner incorrectly manipulates the linguistic system of his mother tongue to create new grammatical structures in the target language. On the other hand, intralingual errors, also described as developmental errors (Dulay et al., 1982), occur during the learning process of the second language at a stage when the learners have not really acquired the knowledge.

In relation to this, Richards (1974, p. 181) proposes four types of intralingual errors; namely overgeneralisation, ignorance of rule restriction, incomplete application of rules and the building of false systems. First, overgeneralisation takes place when a learner extends the use of a grammatical rule beyond its accepted usage, e.g. he produces a sentence like *I meeted him while the childs were playing instead of I met him while the children were playing. In this case, the learner applied the regular form markers (-ed and -s) to all the English verbs and nouns. Second, the learner's ignorance of rule restriction occurs when he fails to understand that the existing rule is restricted to a specific context and therefore should not be applied in other contexts. For instance, he misuses the wrong form after the modal verb and writes *They didn't can come early instead of They couldn't come early. In this case, the learner thinks that the modal verb can is like the other action verbs such as didn't jump, didn't ask, didn't talk etc., and therefore the rule was applied wrongly. The third intralingual error - incomplete application of rules - occurs when the learner fails to learn the more complex types of structure because he finds that he can successfully express himself using simple rules rather than the more complex ones, e.g. *You speak English? instead of Do you speak English? Another example is when the learner omits the verb inflection, i.e. he does not add (-s) to form the third person singular as in *She write English or omits the verb to be and produces sentences like *It good and They running rather than It is good and They are running. Finally, in agreement with Corder's learners' false hypothesis (1971), Richards (1974) points out that errors may arise when learners do not fully understand the system of the target language.
In addition, Dulay et al. (1982, pp. 163-173) classified learners' errors into two taxonomies: comparative and communicative effect. The first includes four types of errors namely: interlingual (errors which reflect the linguistic system of L1), developmental (errors similar to those made by children learning English as a first language), ambiguous (errors which are either developmental or interlingual) and unique (those that are neither developmental nor interlingual). Communicative effect taxonomy deals with errors from the perspective of their effect on the reader and listener, i.e. whether they produce miscommunication or not. These errors are either global or local. While the first causes misunderstanding and affects the learner's comprehension of the intended word, phrase, or sentence, which therefore hinders successful communication, the second does not.

Taylor (1986) views the causes of learners' errors from a different perspective and describes them as psycholinguistic, sociolinguistic, epistemic and discourse-related. While psycholinguistic errors concern the L1 system and the difficulties which learners encounter while learning it, the sociolinguistic ones involve the learner's ability to adapt his L1 to the social context of L2. Errors which occur due to the learner's lack of knowledge are called epistemic whereas those arising from a lack of producing coherent text is referred to as discourse-related.

Later, James (2013, pp. 179-200) introduces four major causes of errors: interlingual, intralingual, communication strategy-based and induced errors. He agrees with the other researchers who state that interlingual errors result from the learner's mother-tongue influence as the learner negatively transfers some items from his L1 to the target language. However, he points out that intralingual errors are learning strategy-based errors. James identifies seven types of intralingual errors namely false analogy, misanalysis, incomplete rule application, overgeneralisation, exploiting redundancy, overlooking co-occurrence restrictions and hypercorrection. All these types of intralingual errors were highlighted previously by Corder (1971) and Richards (1974) except for exploiting redundancy and hypercorrection. According to James, exploiting redundancy results from learner's unnecessary repetition of morphemes, words, phrases, and so forth as in She sat alone *by herself and They entered in turn *one after the other. Moreover, James (2013, p. 186) argues that hypercorrection 'results from the learners over-monitoring their L2 output'. That is to say, the learner gives extra care in speech or writing especially in an attempt to produce a sentence in quite a formal manner, for instance, This is a five-unit*s book. James (2013) also introduces another cause of errors based on communication strategy. He suggests two types of errors that result from strategies used by language learners: holistic and analytic. A holistic error takes place when the learner substitutes the required L2 form with another near-equivalent word, e.g. horse for animal and airplane for helicopter whereas an analytic strategy error result from using too many words to express an idea, instead of saying it directly. This occurs when the learner forgets or does not know the target word and tries to describe in his own words. Thus, he writes $I$ watched the football match in the big sports place rather than ... in the stadium. The last cause of learners' errors is induced 
errors which result from classroom situation. James suggests the subcategories of induced errors: materials-induced errors, teacher-talk induced errors, exercise-based induced errors, errors induced by pedagogical priorities and look-up 'dictionary' errors. A summary of all the causes of learners' errors is shown in Table 6 below.

\section{The Limitations of Error Analysis}

EA appeared in the field of applied linguistics in the late 1960s and 1970s as a useful procedure to eliminate some of the shortcomings of CA which views language learning as a set of habit formation and claims that the learner's mother

Table 6. A summary of the causes of learner errors

\begin{tabular}{|c|c|}
\hline Researchers & Causes \\
\hline $\begin{array}{l}\text { Corder } \\
(1971)\end{array}$ & $\begin{array}{l}\text { 1. Mother tongue interference } \\
\text { 2. Learner's false hypothesis }\end{array}$ \\
\hline $\begin{array}{l}\text { Richards } \\
\text { (1974) }\end{array}$ & $\begin{array}{l}\text { 1. Interlingual (mother tongue interference) } \\
\text { 2. Intralingual (developmental) including: } \\
\text { a. overgeneralisation } \\
\text { b. ignorance of rule restriction } \\
\text { c. incomplete application of rules } \\
\text { d. learner's false hypothesis }\end{array}$ \\
\hline \multirow[t]{2}{*}{$\begin{array}{l}\text { Dulay et al. } \\
\text { (1982) }\end{array}$} & $\begin{array}{l}\text { 1. Comparative Taxonomy } \\
\text { a. interlingual errors } \\
\text { b. developmental errors } \\
\text { c. ambiguous errors } \\
\text { d. unique errors }\end{array}$ \\
\hline & $\begin{array}{l}\text { 2. Communicative Effect Taxonomy } \\
\text { a. global errors } \\
\text { b. local errors }\end{array}$ \\
\hline $\begin{array}{l}\text { Taylor } \\
(1986)\end{array}$ & $\begin{array}{l}\text { 1. Psycholinguistic } \\
\text { 2. Sociolinguistic } \\
\text { 3. Epistemic } \\
\text { 4. Discourse-related }\end{array}$ \\
\hline $\begin{array}{l}\text { James } \\
(2013)\end{array}$ & $\begin{array}{l}\text { 1. Interlingual (mother tongue interference) } \\
\text { 2. Intralingual (target language causes) } \\
\text { including: }\end{array}$ \\
\hline & $\begin{array}{l}\text { a. Learning strategy-based errors } \\
\text { i. false analogy } \\
\text { ii. misanalysis } \\
\text { iii. incomplete rule application } \\
\text { iv. exploiting redundancy } \\
\text { v. overlooking restrictions } \\
\text { vi. hypercorrection } \\
\text { vii. overgeneralisation }\end{array}$ \\
\hline & $\begin{array}{l}\text { b. Communication strategy-based errors } \\
\text { i. holistic } \\
\text { ii. analytic }\end{array}$ \\
\hline & $\begin{array}{l}\text { c. Induced errors } \\
\text { i. material-based } \\
\text { ii. teacher-talk } \\
\text { iii. exercise-based } \\
\text { iv. look-up error } \\
\text { v. errors induced by pedagogical priority }\end{array}$ \\
\hline
\end{tabular}

tongue is the principal cause of difficulty in learning another language. During its heyday, EA was considered important theoretically and practically because it served linguists, psycholinguists, teachers and learners as well. In spite of this, EA is criticised by many language researchers. They claim that one major drawback with EA is that it considerably relies on errors and excludes other information. Schachter (1974) argues that EA is inadequate and needs to take into consideration both errors and non-errors in order to get a comprehensive picture of the learner's linguistic development. Placing too much attention on errors hinders the learner's language proficiency and makes teachers and researchers reduce the value of correct performance which is the primary goal of learning a second language (Brown, 2000). Another criticism of EA is that it does not take into consideration the strategy of avoidance, i.e. a learner can avoid making errors by replacing certain doubtful L2 words, idiomatic expressions, structures, sounds etc. with other language items which he feels quite confident with (Schachter, 1974). By doing this, a learner can write, for example, a paragraph without a single error. However, Brown (2000, p.219) argues that 'the absence of error does not necessarily reflect native-like competence.' Another weakness is that EA neglects receptive skills, i.e. listening and reading, and focuses purely on the productive ones, i.e. speaking and writing. This is clearly apparent in most EA previous studies conducted. Finally, Dulay et al. (1982) consider the lack of sufficient precision in the definition of error categories as another one of EA's weakness. They reported that most studies conducted on EA could not precisely explain the causes of learners' errors and their findings were imprecise and considerably confusing to the reader. To clear this confusion, James (2013) reviewed previous literature and suggested a more thorough and comprehensive taxonomy by describing learners' errors in terms of linguistic categories and surface strategy, and explaining that errors can be interlingual, intralingual, strategy-based or induced through instruction (see Table 6). In spite of all the weaknesses pointed out, EA is still alive and well in the field of SLA, with many of the criticisms deflected by later researchers. Crystal (2010, p.377) claims that 'research into errors continues to provide a fruitful way of investigating the processes underlying FL [foreign language] acquisition.'

Up to this point, the discussion has included only two language learning approaches, i.e. CA and EA. Whilst the first was introduced by behaviourists who viewed language learning as a mechanical process of habit formation, the second, i.e. EA made use of mentalism which viewed language learning development as a systematic process through which a learner used his mental capacity creatively rather than 'mouthing off like a parrot'. However, researchers like Corder (1971), Nemser (1971), and Selinker (1972) undervalue the importance of the EA approach, and pay more attention to the stages of language learning development. As the learners go through these stages, their language proficiency level in the target language increases. Accordingly, learners formulate hypotheses about the structure of the L2, construct rules, try them out, and change them if they prove to be inadequate (Crystal, 2010). Interestingly, the linguistic system which the learn- 
er develops is referred to as interlanguage, and it relates to neither L1 nor L2.

\section{INTERLANGUAGE HYPOTHESIS}

The term interlanguage (IL, hereafter) was coined by the American linguist Larry Selinker (Ellis, 1997). However, other language researchers used different terms to describe the same phenomenon. Corder (1981) refers to it as an idiosyncratic dialect whereas Nemser, (1971) calls it approximative systems. Regardless of the different terms proposed, Ellis (1985, p.299) defines IL as 'the systematic knowledge of a second language which is independent of both learner's first language and the target language'. According to this view, language is seen as a separate intermediate linguistic system (see Figure 1).

While EA focuses merely on the erroneous utterances committed by the learner due to L1 and L2, IL is viewed as 'an autonomous linguistic system in its own right that evolved according to innate and probably universal processes' (Han \& Tarone, 2014, p. 8). The main characteristic which makes the IL hypothesis different from CA and also EA is that 'it is wholly descriptive and avoids comparison' (James, 2013, p. 6). This fact caused a revolution in L2 research and teaching because it was the first time a learner's imperfect L2 system was understood as an autonomous system. The proponents of IL claim that a learner produces a third language which differs from both L1 and L2. This language has its own salient features, and therefore should be studied on its own.

According to Saville-Troike (2006), IL has some distinctive characteristics. First, it is systematic and governed by rules which constitute the learner's internal grammar. These rules can be discovered and analysed based on the learner's language, i.e. oral or written production. This includes the learner's correct structures as well as his errors. Second, IL is considered dynamic as the learner's system of rules is not stable, i.e. it changes frequently. Thus, language learning is seen as a discontinuous development moving 'from stable plateau to stable plateau' (Selinker, 1992, p. 226). Third, IL has a reduced system, i.e. the learner uses limited sets of forms and functions. In other words, he uses 'less complex syntactic structures and smaller range of communicative needs compared to L2' (Saville-Troike, 2006, p. 41). Finally, IL is variable in spite of being systematic. That is to say, a learner's language use varies from one context to

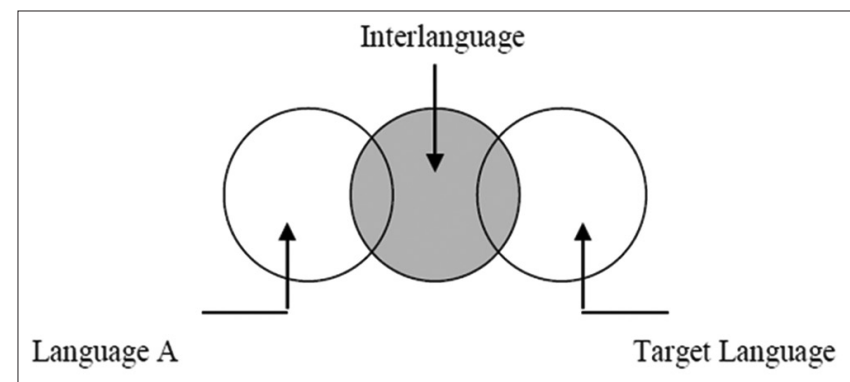

Figure 1. A Diagram of Interlanguage (Source: Corder, 1981, p. 17) another. Ellis (1988) and Young (1988) revealed that different linguistic contexts cause variability in the learners' interlanguage of using a linguistic item. For example, the L2 learners' performance of tasks may vary from one task to another. To put it differently, language learners use different strategies and techniques to obtain information about the rules and the systems they are using.

Han and Tarone (2014, pp.9-12) argue that IL is not a theory but rather a hypothesis (a question-answer model) which poses a set of questions originated from one crucial question: What if learner language is a linguistic system? This makes researchers think profoundly, raise questions, offer different answers to understand the nature of this underlying system clearly. Mitchell and Myles (2004) describe IL as systematic in a way that it abides by certain internal rules, and is dynamic because it evolves over time. According to Nemser (1971, cited in Ellis, 1985, p.47), IL is based on 'three main assumptions that: (1) at any given time, the approximative system is distinct from the L1 and L2; (2) the approximative system forms an evolving series; and (3) in a given contact situation, the approximative system of the learners at the same stage of proficiency roughly coincide'. Based on these assumptions, the language systems which the learner communicates in are classified into native language (through which linguistic transfer occurs), target language (which the learner attempts to use), and an approximative system (a deviant linguistic system developed by the learner to practice L2). The latter, as Richards (1972) puts it, is 'divergent from L1 and L2 according to the learner's proficiency level, personality, learning experience and communication function'.

\section{Interlanguage Cognitive Processes}

According to Selinker (1972, as cited in Grauberg, 1997, p. 78), IL is the product of five central processes: language transfer, transfer of training, strategies of L2 learning, strategies of L2 communication and overgeneralisation of L2 rules. Language transfer occurs when the learner carries over some linguistic elements from his mother tongue to the target language. When the transferred elements, e.g. words, phrases, sounds are different from L2 rules, they negatively hinder the process of learning. Transfer of training, meanwhile, takes place when a prior training or teaching method affects the learner's performance of the current situation, e.g. a classroom activity. Strategies of second language learning occurs when the learner attempts to employ a certain strategy to develop his linguistic competence in L2. Furthermore, strategies of second language communication are about the ways which the learner uses to communicate with others including native speakers. Finally, overgeneralisation of $\mathrm{L} 2$ rules takes place when the learner extends L2 beyond its correct use. If we quickly glance at the processes which Selinker suggests, we can see that these are the same causes of errors which were discussed previously in (see Table 6). This presents clear evidence that interlanguage plays an important role in exploring the causes underlying the learners' errors, as well as making researchers adequately understand the nature of learner's internal linguistic system and how it functions. 


\section{REFERENCES}

Awasthi, J. R. (1995). A linguistic analysis of errors committed by Nepali learners of English (Unpublished doctoral dissertation), University of Hyderabad, India.

Brown, H. D. (2000). Principles of Language Learning and Teaching. $\left(4^{\text {th }}\right.$ Ed). Addison Wesley, New York: Longman.

Brown. H. D. (2007). Principles of Language Learning and Teaching ( $\left.5^{\text {th }} \mathrm{Ed}\right)$. Addison Wesley, New York: Longman.

Burt, M. \& Kiparsky, C. (1972). The Gooficon: A Repair Manual for English. Newbury House.

Chomsky, N. (1959). A review of BF Skinner's Verbal behavior. Language, 35(1), 26-58.

Cook, V. J. (1999). Teaching spelling. Retrieved January 17, 2019 from www.essex.ac.uk/ vcook

Corder, S. P. (1971) Idiosyncratic Dialects and Error Analysis. In J.C. Richards (ed.) (1974) Error Analysis: Perspectives on Second Language Acquisition (pp. 158171). London: Longman.

Corder, S.P. (1973). Introducing Applied Linguistics. Harmondsworth, UK: Penguin Books Ltd.

Corder, S.P. (1978) Language-learner Language. In J.C. Richards (ed.) Understanding Second and Foreign Language Learning (pp. 71-93). Rowley, MA: Newbury House.

Corder, S.P. (1981). Error Analysis and Interlanguage. Oxford University Press.

Crystal, D. (2010). The Cambridge Encyclopedia of Language. Cambridge University Press.

Crystal, D. (2008). A dictionary of linguistics and phonetics. ( $5^{\text {th }}$ Ed.). London: Blackwell.

Dulay, H., \& Burt, M. (1974). Error and strategies in child second language acquisition. TESOL Quarterly, 8, 129-138.

Dulay, H., Burt, M. \& Krashen, S. (1982). Language Two. Oxford University Press.

El-Dakhs, D. and Mitchell A. (2011). Spelling Error Analysis among EFL High-School Graduates. Retrieved on 3 January 2019 from http://www.ksaalt.org

Ellis, R. (1985). Understanding Second Language Acquisition. Oxford University Press.

Ellis, R. (1994). The Study of Second Language Acquisition. Oxford University Press.

Ellis, R. (1997). Second Language Acquisition. Oxford Introduction to Language Study. Series Editor H. G. Widdowson.

Ellis, R. (1988). The Effects of Linguistic Environment on the Second Language Acquisition of Grammatical Rules. Applied Linguistics 10, 281-302.

Ferris, D. R. (2011). Treatment of Error in Second Language Student Writing. Ann Arbor: The University of Michigan Press.

Fisiak, J. (1981). The Study of Second Language Acquisition. Oxford: Oxford University Press.

Grauberg, W. (1997). The elements of foreign language teaching (Vol. 7). Multilingual Matters.

Han, Z., \& Tarone, E. (Eds.). (2014). Interlanguage: Forty years later (Vol. 39). John Benjamins Publishing Company.

James, C. (2013). Errors in language learning and use: Exploring error analysis. Routledge...
Keshavarz, M. H. (2003). Contrastive Analysis and Error Analysis. Rahnama Publications Tehran.

Lado, R. (1977) Linguistics across Cultures. Ann Arbor: University of Michigan Press.

Littlewood, W. (1984). Foreign and Second Language Learning: Language Acquisition Research and Its Implications for the Classroom. Cambridge University Press.

López Castillejos, W. (2009). Error Analysis in a Learner Corpus. What Are the Learners' Strategies? Retrieved on $14^{\text {th }}$ March 2019 from http://www.corpus4u.org/forum.

Mitchell, R. and Myles, M. (2004). Second Language Learning Theories. New York: Hodder Arnold.

Nemser, N. (1971). Approximate Systems of Foreign Language Learners. IRAL, 9(2) 115-124.

Nickel, G. (1971). Papers in Contrastive Linguistics. London: Cambridge University Press.

Oller, J. W. \& Ziahossieny, S. M. (1970). The Contrastive Analysis Hypothesis and Spelling Errors in Language Learning. Vol 20.

Politzer, R. and Ramirez, A. (1973). An Error Analysis of Spoken English of Mexican-American Pupils in a Bilingual School and a Monolingual School, Language Learning, 23(1), 39-61..

Powell, G. (1998). What is the Role of Transfer in Interlanguage? Department of Linguistics and Modern English Language, Lancaster University. Retrieved on $20^{\text {th }}$ February 2019 from www.ling.lancs.ac.uk/groups/crile/ workingpapers.

Richards, J. C. (1974). Errors Analysis Perspectives on Second Language Acquisition. Applied Linguistics and Language Study. Longman Group Limited, London.

Richards, J. \& Sampson, G. (1974). The Study of Learner English. In Errors Analysis Perspectives on Second Language Acquisition. Applied Linguistics and Language Study. Longman Group Limited, London. pp. 6-8.

Richards, J. C. \& Schmidt, R. (2010). Longman Dictionary of Language Teaching \& Applied Linguistics. $\left(4^{\text {th }} \mathrm{Ed}\right)$. Pearson Education Limited.

Saville-Troike, M. (2006). Introducing Second Language Acquisition. Cambridge Introduction to Language and Linguistics. Cambridge University Press.

Schachter, J. (1974). An error in error analysis. Language Learning, 24, 205-214.

Selinker, L. \& Gass, S. (2008). Second Language Acquisition: An introductory course. Mahwah, NJ: Erlbaum.

Selinker, L. (1992). Rediscovering Interlanguage. London: Longman.

Selinker, L. (1972), Interlanguage. International Review of Applied Linguistics, 10, 209-231.

Spolsky, B. (1979). Contrastive analysis, error analysis, interlanguage, and other useful fads. The modern language journal, 63(5-6), 250-257.

Sridhar, S. (1980). Contractive Analysis, Error Analysis and Interlanguage: Three Phases of one Goal. "Readings on English as a second Language. Croft, K. (ed.) Cambridge. Massachusetts: Winthrop publisher.

Swalameh, M. H. M. (2013). Error Analysis of Written English Essays: the Case of Students of the Preparatory 
Year in Saudi Arabia. English for Specific Purposes World. Vol.14.

Taylor, G. (1986). Errors and Explanations. Applied Linguistics, 7,144-66.

VanPatten, B. \& Benati, A. G. (2010). Key Terms in Second Language Acquisition. London: Continuum International Publishing Group.

Weireesh, S. (1991). How to Analyze Interlanguage. Journal of Psychology \& Education.9 (1), 13 -22.
Zampieri, M. and Amorim, R. C. (2014). Between Sound and Spelling: Combining Phonetics and Clustering Algorithms to Improve Target Word Recovery. In Advances in Natural Language Processing. $9^{\text {th }}$ International Conference, Warsaw, Poland.

Zawahreh, F. A. S. (2012). Applied Error Analysis of Written Production of English Essays of Tenth Grade Students in Ajloun Schools, Jordan. International Journal of Learning and Development, 2(2). 